\title{
Cerebrospinal fluid cholinesterase activity in children with meningitis
}

\author{
Mohammed Khalid Jamal-Aldeen Alnoori \\ College of pharmacy, University of Mosul, Iraq

$\frac{\text { Received }}{\text { rq.9.2010 Accepted }}$

\begin{abstract}
Objective: To assess the changes of cerebrospinal fluid (CSF) acetyl cholinesterase (AChE) activity in children with acute bacterial meningitis in comparison to healthy age and sex matched controls.
\end{abstract}

Patients and methods: Out of 41 cases admitted to Alkhansaa pediatric and dilivery hospital (Mosul city) between January 2010 and July 2010, 28 cases proved to be a case of Haemophilus influenzae meningitis, 13 child proved lack from any type of meningitis with age and sex matched subjects taken as a control group. Initially from all of the studied children (patients and controls) about $5 \mathrm{ml} \mathrm{CSF}$ samples were taken and assayed for appearance, leucocytes, red blood cells, sugar, protein and AChE activities by spectrophotometric method.

Results: There were a significant increase in CSF WBCs count, RBCs count, protein levels, AChE activity with a decrease in CSF glucose level for children with acute bacterial meningitis in comparison to the control group.

Conclusion: There is an important value for measurement of CSF AChE activity for confidential diagnosis of children with acute bacterial meningitis specially for those with equivocal decision by using the traditional parameters.

Keywords: Bacterial meningitis, CSF AChE.

$$
\begin{aligned}
& \text { الخلاصة } \\
& \text { أهداف البحث: لتحديد أهمية قياس مستوى التغيير لنشاط خميرة الكولين استراز في سائل النخاع ألثوكي }
\end{aligned}
$$

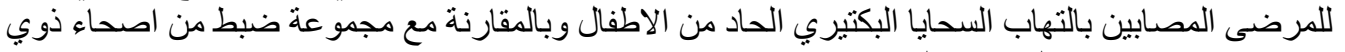

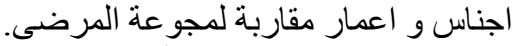

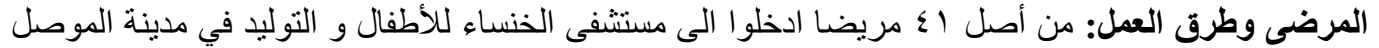

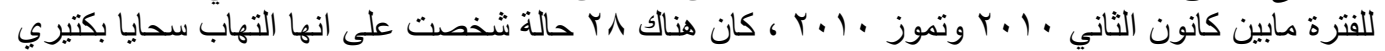

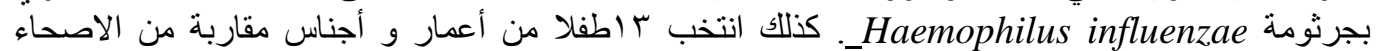

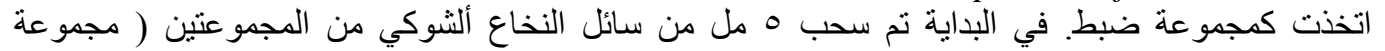

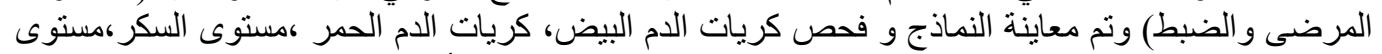

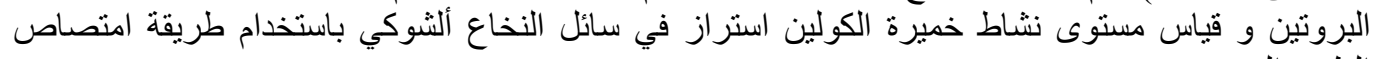

$$
\begin{aligned}
& \text { الطيف الضوئي. } \\
& \text { النتائج: هنالك زيادة معنوية في كريات الدم البيض، كريات الدم الحمر، مستوى البروتين و مستوى نشاط خميرة }
\end{aligned}
$$

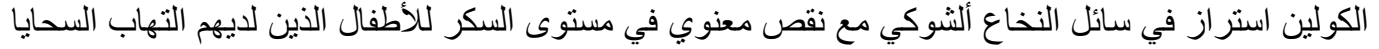

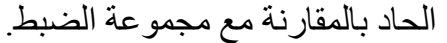

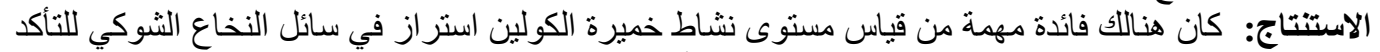

$$
\begin{aligned}
& \text { من صحة تتخيص التهاب السحايا البكتيري الحاد عند الأطفال الذين لم يكتمل تشخيصهم للمرض التهن باستخدام طرق } \\
& \text { الكثف الاعتبادية . }
\end{aligned}
$$


other illnesses such as aseptic (viral) meningitis. This is particularly true in young children and infants, making diagnosis in the pediatric age group especially problematic. There is a prevalent myth that CSF, white cell counts and other surrogate markers are reliable indicators of bacterial versus viral infections. This is a dangerous misconception $^{2-4}$.

A reliable means of distinguishing between bacterial and viral central nervous system (CNS) infections would reduce the risk and expense of unnecessary antibiotic therapy and hospitalization in aseptic meningitis patients ${ }^{5}$.

The most important diagnostic study for patients with possible meningitis is lumbar puncture with CSF analysis. The gold standard for diagnosing bacterial meningitis is the CSF culture, despite its limited value in patients who have been partially treated. However, physicians must make treatment decisions before culture results are available, and they depend on CSF findings such as cell count, glucose, protein, and Gram's stain to help them do so ${ }^{6,7}$.

Other CSF studies have been advocated as a means of distinguishing bacterial from aseptic meningitis. These include CSF leukocyte aggregation, ${ }^{8} \mathrm{CSF}$ lactate ${ }^{9}$ and $\mathrm{CSF}$ cytokine levels, among others. Many authors have studied these tests, but have not conclusively demonstrated their utility. Bacterial antigen studies, more widely used, also have limited utility during the initial patient encounter.To date, no single diagnostic model has been validated in an adequate sample of patients as anything more than an adjunct to physician judgment. The aim of the study is to determine the changes of CSF cholinesterase activity in children with acute bacterial meningitis in comparison to healthy age and sex matched controls.

\section{Patients and methods}

This study was conducted from January to July 2010. Children with positive signs of meningitis were admitted to Alkhansaa pediatric and maternity hospital (Mosul city) and immediately a CSF samples were taken. Later positively proved cases of bacterial meningitis (from CSF culture) were selected and included in this study as the case group, whereas the negatively proved cases represented as the control group.

Out of 41 cases admitted to hospital, 28 cases proved to be bacterial meningitis (all due to Haemophilus influenzae). They were 11 females with 17 males with a mean \pm SD age $3.25 \pm 2.08$ years (ranged between .5 and 8 years). Also included 13 apparently healthy children as a control group. They were 5 females and 8 males with a mean \pm SD age $3.58 \pm 2.53$ years (ranged between .6 and 8.5 years).

Initially around $5 \mathrm{ml} \quad \mathrm{CSF}$ samples were taken from patients and control, and assay of appearance, WBC count, RBC count, glucose concentrations were measured by enzymatic colorimetric method which was available as a kit purchased from Biomaghreb $^{10}$, protein concentrations were measured by bromocresol green (BCG) method which was available as a kit purchased from Randox Laboratories $\operatorname{Ltd}^{11,12}$, and $\mathrm{ChE}$ activities were measured by spectrophotometric Ellman et al. method, after centrifugation of the CSF sample at $3000 \mathrm{rpm}$ for $5 \mathrm{~min}^{13}$.

\section{Statistical analysis}

All values were quoted as mean $\pm \mathrm{SD}$ and a P-value $<0.05$ was considered to be statistically significant. Unpaired ttest was used to compare results of 
patients suffer from bacterial meningitis, with the results of the controls.

$\frac{\text { enzme concentration }(\text { unit } / m L)}{\text { protein concentration }\left(\frac{m g}{m L}\right)}=$
specific activity (unit $/ \mathrm{mg})$

Therefore, the AChE specific activity value of the control group equal to 21.066 nanomol $\mathrm{min}^{-1} \mathrm{mg}^{-1}$, while that of the meningitis group equal to 15.418 nanomol $\mathrm{min}^{-1} \mathrm{mg}^{-1}$. The present study revealed that despite the increase in the CSF protein and AChE activity among patients group versus the control group as shown in Figure 1 and Figure 2, there is a decrease in AChE specific activity in patients group versus control group as shown in Figure 3

Table 1. comparison of CSF WBCs count, RBCs count, protein level, AChE activity and glucose levels between cases of acute bacterial meningitis and the controls.

\begin{tabular}{|c|c|c|}
\hline Parameters & Controls $(\mathrm{n}=13)$ & Cases before therapy $(\mathrm{n}=28)$ \\
\hline CSF WBCs count & $17 \pm 2.76$ leukocyte $/ \mu \mathrm{L}$ & $237 \pm 43.76$ leukocyte $/ \mu \mathrm{L}^{*}$ \\
\hline CSF RBCs count & $.08 \pm .013 \mathrm{RBC} / \mu \mathrm{L}$ & $3.42 \pm .55 \mathrm{RBC} / \mu \mathrm{L}^{*}$ \\
\hline CSF protein & $390.2 \pm 71.2 \mathrm{mg} / \mathrm{L}$ & $775.38 \pm 131.86 \mathrm{mg} / \mathrm{L}^{*}$ \\
\hline CSF AChE & $8.22 \pm 1.72$ nanomol min ${ }^{-1} \mathrm{ml}^{-1}$ & $11.955 \pm 2.62$ nanomol min ${ }^{-1} \mathrm{ml}^{-1} *$ \\
\hline CSF glucose & $4.58 \pm .68 \mathrm{mmol} / \mathrm{L}$ & $2.87 \pm .49 \mathrm{mmol} / \mathrm{L}^{*}$ \\
\hline${ }^{*} \mathrm{p}<0.001$ & &
\end{tabular}




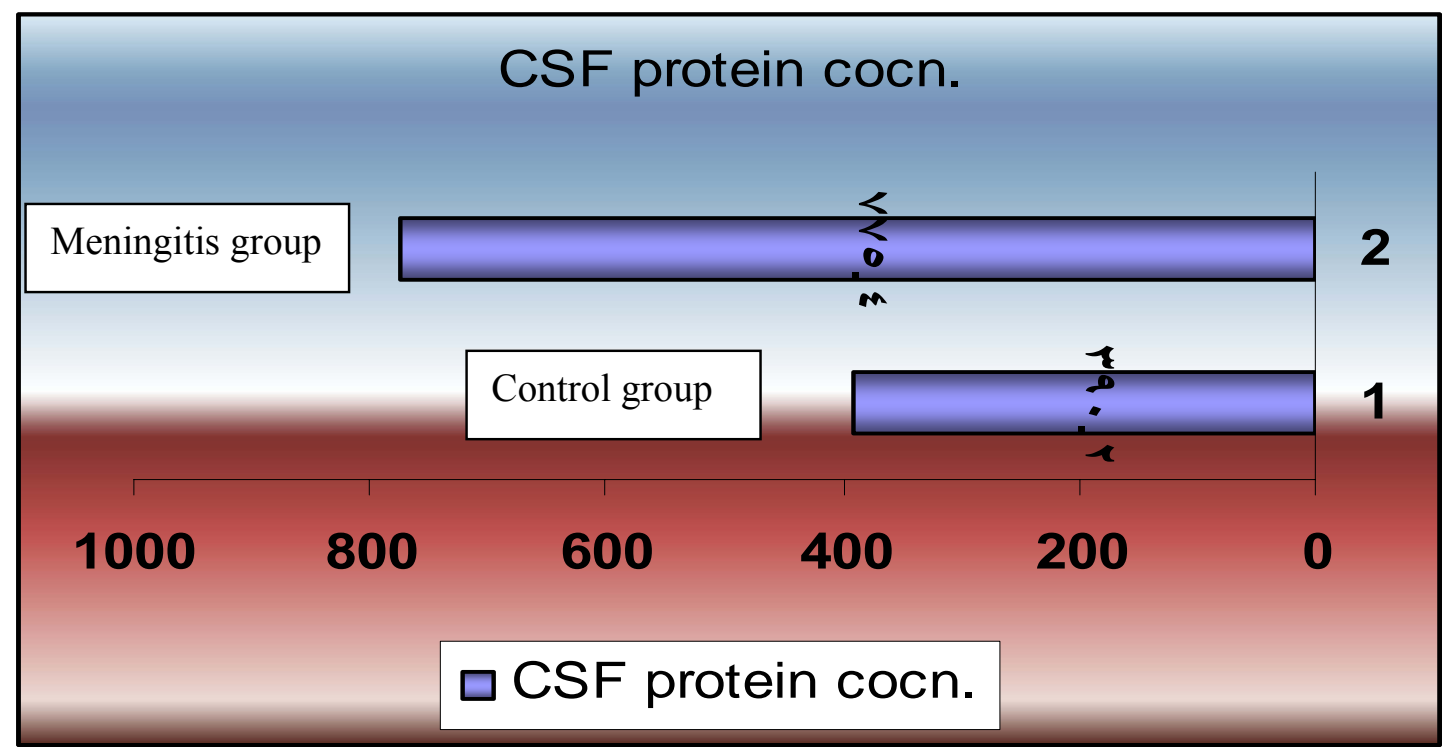

Figure 1. Distribution of CSF protein concentrations among control subjects versus patients group

\section{CSF AChE}

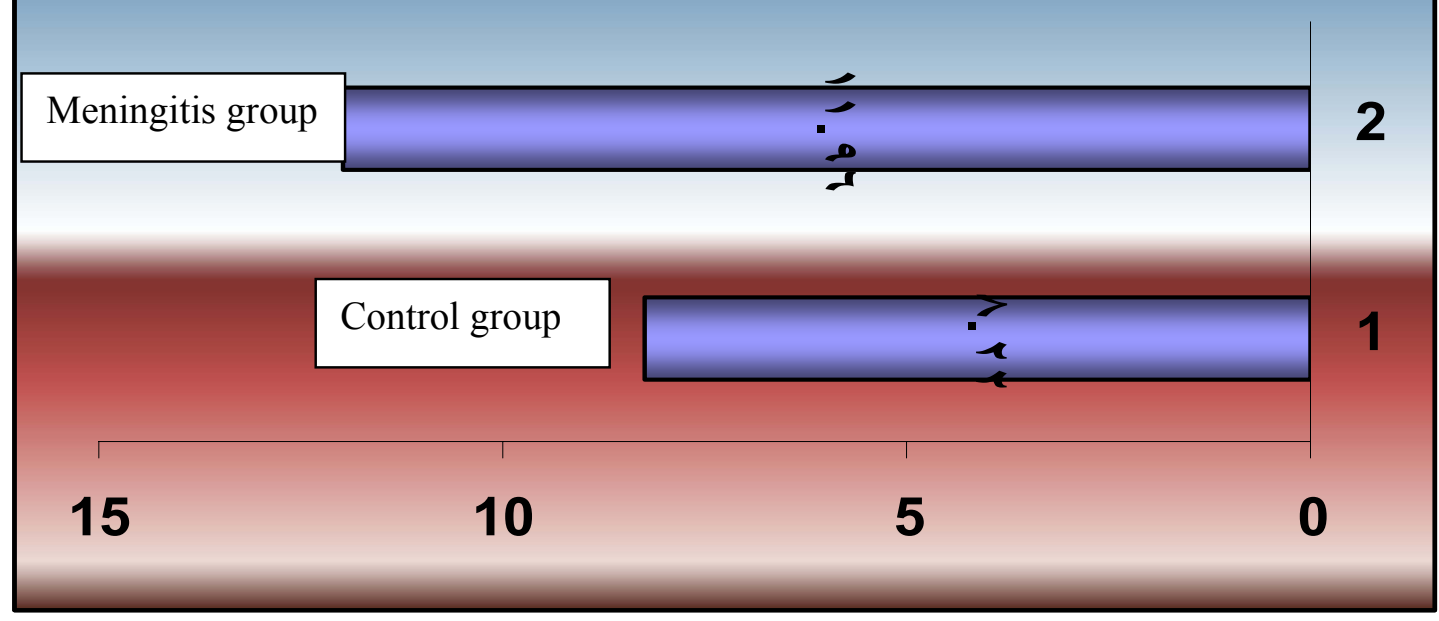

Figure 2. Distribution of CSF AChE activity among control subjects versus patients group 


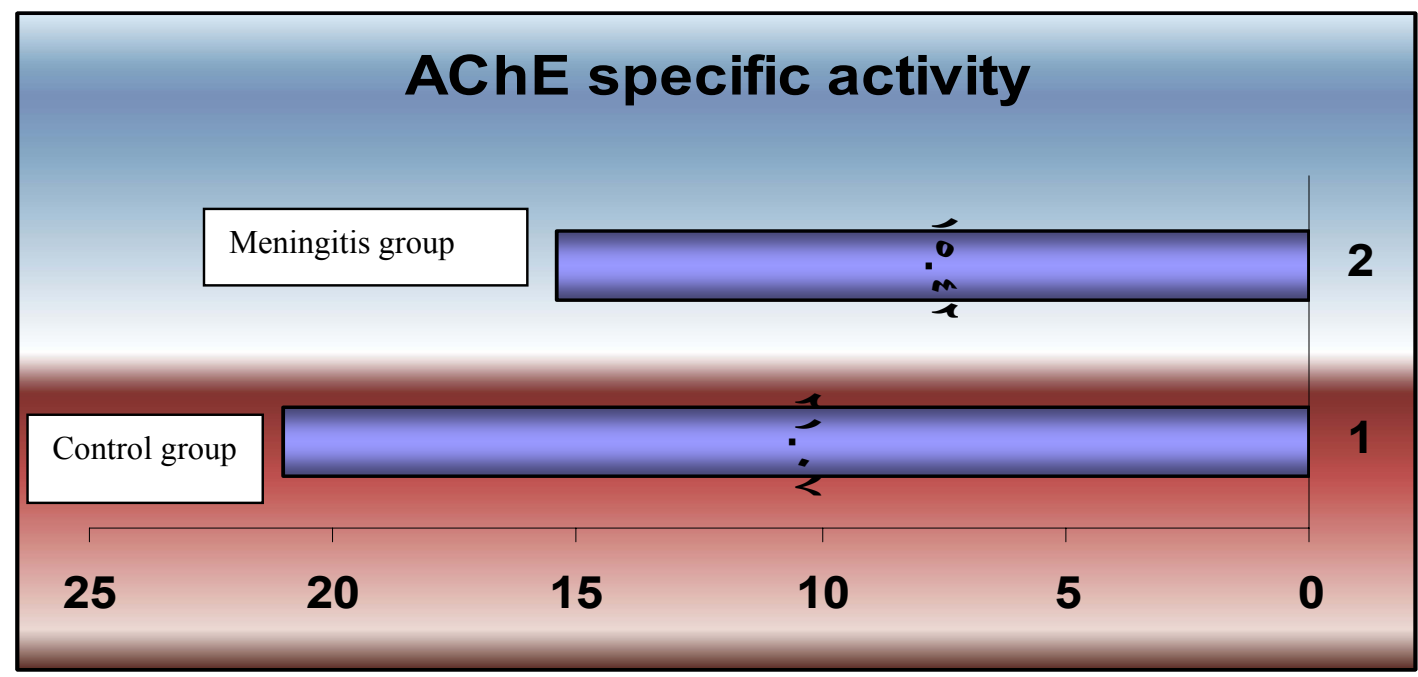

Figure 3. Distribution of CSF AChE specific activity among control subjects versus patients group

\section{Discussion}

Distinguishing acute, subacute, and chronic meningitis helps identify the pathogen. Approximately $25 \%$ of patients with bacterial meningitis present acutely, well within 24 hours of onset of symptoms. Other patients with subacute bacterial meningitis and most patients with viral meningitis present with neurologic symptoms developing over 1-7 days. Chronic symptoms lasting longer than 1 week suggest meningitis caused by some viruses as well as tuberculosis, syphilis, fungi (especially cryptococci), and carcinomatous meningitis ${ }^{15}$.

This study shows a significant increase in CSF WBCs count, CSF RBCs count, CSF protein levels, with a decrease in CSF glucose level for children with acute bacterial meningitis in comparison to the control group. Once in the CSF, the paucity of antibodies, complement components, and WBCs allow the bacterial infection to flourish. Bacterial cell wall components initiate a cascade of complement and cytokine-mediated events that result in increased permeability of the blood-brain barrier, cerebral edema, and presence of toxic mediators in the CSF. Replicating bacteria, increasing numbers of inflammatory cells, cytokine-induced disruptions in membrane transport, and increased vascular and membrane permeability perpetuate the infectious process and account for the characteristic changes in CSF cell count, protein, and glucose ${ }^{16}$. Baker and Lenane (1989) showed that, in patients with bacterial meningitis, CSF white blood cell (WBC) counts are at least 300-2000 cells $/ \mathrm{mm}^{17}$

The pathologic whole mark of bacterial meningitis is subarrchenoid space exudates, microscopically examination of this exudates in the early stage must demonstrate a large numbers of neutrophils and bacteria. Within 2-3 days of infection evidence of inflammation in the wall of the small and medium size subarrchenoid blood vessels appeared as infiltration of lymphocytes and neutrophils in the wall of the meningeal veins which become distended with local necroses in the wall ${ }^{18}$.

The leakage of RBCs, WBCs, and proteins to the CSF may follow and it may contribute the increase numbers of CSF-RBCs, CSF-WBCs 
and CSF-protein level, and these may represent the major and the first findings for the diagnosis of bacterial meningitis ${ }^{19}$. Dean etal (2003) showed an increase in CSF RBCs count for patients with bacterial meningitis ${ }^{20}$.

As the typical CSF findings in acute bacterial meningitis consist of neutrophelic polycytosis, may be explained by the leakage of these cells from the focal necrotic lesions in the wall of subarrchenoid blood vessels, also the elevated CSF-protein concentration and the abnormal presence of RBCs in the CSF fluid may be attributed to the necrosis in the wall of subarrchenoid blood vessels, or these changes in CSF-RBCs, CSFWBCs and CSF-protein level may be caused by the affection of the inflammation of the meninges on the normal barrier between the CSF and the blood circulation ( $\mathrm{i}$,e the bloodbrain barrier BBB). Thomas etal (2003) stated that the CSF protein levels are above $150 \mathrm{mg} / \mathrm{dL}(>1.5 \mathrm{~g} / \mathrm{L})$ for those with bacterial meningitis ${ }^{6}$. However Several authors have demonstrated, that the CSF leukocytes count cannot reliably distinguish between bacterial and aseptic meningitis ${ }^{7,14}$

Dean et al. ${ }^{20}$ reported that CSF glucose concentration is expected to be below $40 \mathrm{mg} / \mathrm{dL}(<2.5 \mathrm{mmol} / \mathrm{L})$, with a CSF:serum ratio of $<0.25$. This reduction in the CSF-glucose level may be the finding of the consumption of different types of cells accumulated in the CSF of patients with bacterial meningitis that not present in normal CSF.

This study demonstrates a significant increase in CSF AChE activity for children with bacterial meningitis, this finding is consisted with previous studies ${ }^{21,22}$.

The destructions of several CSFRBCs cause the release of intraerythrocytic $\mathrm{AChE}$ to the $\mathrm{CSF}$, or the leakage of plasma $\mathrm{AChE}$ across the abnormal $\mathrm{BBB}$ in case of meningitis can explain the increase of CSF-AChE activity in case of bacterial meningitis.

Despite the significant increase of CSF-AChE activity in meningitis group versus the control group, there is a reduction in the $\mathrm{AChE}$ specific activity in the meningitis group versus the control group. This finding show that the increase in the concentration of CSF-Protein is much higher than the increase in the activity of CSF-AChE among patients with bacterial meningitis, so still measurements of CSF-protein level are more important than the measurement of CSF-AChE and the measuring of CSF-AChE can not represent the measuring of CSFprotein, but can augment the other measures for the diagnosis.

In conclusions measurement of CSF- AchE activity in suspected cases of acute bacterial meningitis in children can help in the diagnosis and give an additional information to confirm the diagnosis specially for those with equivocal decision.

\section{References}

1. Kaplan SL. Clinical presentations, diagnosis, and prognostic factors of bacterial meningitis. Infect Dis Clin North Am 1999;13:579-94.

2. Van de Beek D, de Gans J, Tunkel AR, Wijdicks EF. Communityacquired bacterial meningitis in adults. N Engl J Med 2006;354(1):44-53.

3. Thigpen M, Rosenstein NE, Whitney CG. Bacterial meningitis in the United States --19982003. Presented at the $43 \mathrm{rd}$ Annual Meeting of the Infectious Diseases Society of America, San Francisco, CA. October 2005;65.

4. Peltola H, Roine I. Improving the outcomes in children with bacterial 
meningitis. Curr Opin Infect Dis 2009;22:250-5.

5. Fitch MT, van de Beek D. Emergency diagnosis and treatment of adult meningitis. Lancet Infect Dis 2007;7(3):191-200.

6. Graham TP. Myth: Cerebrospinal fluid analysis can differentiate bacterial meningitis from aseptic meningitis. CJEM 2003;5(5):3489.

7. Spanos A, Harrell FE Jr, Durack DT. Differential diagnosis of acute meningitis: an analysis of the predictive value of initial observations. JAMA 1989;262: 2700-7.

8. Michelow IC, Nicol M, Tiemessen $\mathrm{C}$, et al. Value of cerebrospinal fluid leukocyte aggregation in distinguishing the causes of meningitis in children. Pediatr Infect Dis J 2000;19:66-72.

9. Ponka A, Ojala K, Teppo AM, Weber TH. Differential diagnosis of bacterial and aseptic meningitis using cerebrospinal fluid laboratory tests. Infection 1983;11:129-31.

10. Lotta JA, Turner K. Evaluation of trinder's glucose oxidase method for measuring glucose in serum and urine. Clin Chem 1975;21:17541760.

11. Silverman LM, Christenson RH. Amino acid and proteins In: Burtis CA, Ashwood ER editors. Tietz textbook of clinical chemistry $2^{\text {nd }}$ ed. Philadelphia: Saunders; 1994. P. 626-734.

12. Negrini B, Kelleher KJ, Wald ER. Cerebrospinal fluid findings in aseptic versus bacterial meningitis. Pediatrics 2000;105:316-9.

13. Ellman GL, Courteny KD, Andres $\mathrm{V}$, Featherstone RM. A new and rapid colorimetric determination of acetylcholinesterase activity. Biochem Pharmacol, 1961;7:88-95.

14. Chenghong Lei, Thereza AS, Yongsoon S, et al. Enzyme specific activity in functionalized nanoporous supports. Nanotechnology 2008;19:125102.

15. Pruitt AA. Infections of the nervous system. Neurol Clin 1998; 16:419-47.

16. Lyons MK, Meyer FB. Cerebrospinal fluid physiology and the management of increased intracranial pressure. Mayo Clin Proc 1990;65:684-707.

17. Baker RC, Lenane AM. The predictive value of cerebrospinal fluid differential cytology in meningitis. Pediatr Infect Dis J 1989;8:329-30.

18. Edlow JA, Caplan LR. Avoiding pitfalls in the diagnosis of subarachnoid hemorrhage. N Eng J Med 2000;342:29-36.

19. Conly JM, Ronald AR. Cerebrospinal fluid as a diagnostic body fluid. Am J Med 1983;751B:102-8.

20. Dean A, Seehusen MD, Mark M, et al. Cerebrospinal Fluid Analysis Tripler Army Medical Center, Honolulu, Hawaii. Am Fam Physicia 2003;68(6):1103-1109.

21. Tornel P L, Vidal C J. CSF Acetyl and butyryl cholinesterase activities in children with bacterial meningitis.

Lancet 1991;337(8738):440.

22. Dickmann U, Soerensen K, Wiedmann T, Mader M, Felgenhauer K. Neuronal AChE in serum and CSF: a prototypic marker for the brain-blood transfer of proteins. J Clin Chem Clin Biochem 1989;27:835. 